\title{
MODEL KOMUNIKASI SOSIAL REMAJA MELALUI MEDIA TWITTER
}

\author{
Zikri Fachrul Nurhadi \\ Program Studi Ilmu Komunikasi, Konsentrasi Public Relations, Universitas Garut \\ Jln. Raya Samarang No. 52A Garut, No. Telp. (0252) 544218 \\ email: kiky_81@yahoo.co.id
}

\begin{abstract}
This research aims to find out and explain the design, experience and sosial interaction in teenager sosial communication through Senior High School. The researcher applied the theory of fenomenology which explains the aware of experince structure togetherwith learning of experience type from the point of view for those people who directly get in touch. This research applied the qualitative method through observation, participant, in dept interview and preferences. This research subjects of the study were high school students as the main informant who represented by purposive sampling technique amounted to 17 people from three SMA Country in Ciamis districts. The result of this research shows that the design is divided in two designs, those are because design and for design. Because design uses the twitter for the development of environment and technology, easy to be used, entertaining, quick send and receive the message, borderless in place and time whereas for design is to get the up to date information, show the existence of them selves, make the social media for doing business, and find out new friends and relation. Whereas communication experience is divided in two, those are positive comunication and negative communcation. Positive communication experience describes the scope of wider twitter, information and promotion media whereas negative communication experience desribes the freedom posting, bad content, killing character and bad communcation. Whereas sosial interaction happens by sending and receiving message effectively, anxiety similarity and giving new cognition.
\end{abstract}

Keywords: Models, Social Communications, Media, Teenagers, Twitter

\begin{abstract}
Abstrak
Penelitian ini bertujuan untuk menemukan dan menjelaskan motif, pengalaman dan interaksi sosial dalam komunikasi sosial remaja pada pelajar SMA. Teori yang digunakan adalah teori fenomenologi yang menjelaskan struktur pengalaman sadar, serta mempelajari bentuk pengalaman dari sudut pandang orang yang mengalaminya langsung. Metode penelitian ini menggunakan pendekatan kualitatif melalui observasi partisipan, wawancara mendalam, dan studi pustaka. Subjek penelitian adalah remaja pelajar SMA sebagai informan utama yang mewakilinya berdasarkan teknik purposive sampling berjumlah 17 orang dari tiga SMA Negeri di Kecamatan Ciamis. Hasil penelitian, menunjukkan motif terbagi menjadi dua, yaitu motif karena dan motif untuk. Motif karena menggunakan media twitter yaitu perkembangan lingkungan pergaulan dan teknologi, mudah digunakan, hiburan, penyampaian serta penerimaan pesan cepat, dan tidak terbatas ruang dan waktu. Motif untuk yaitu mendapatkan informasi yang up to date, menunjukkan eksistensi diri, menjadikan mediasosial untuk berbisnis, serta mencari relasi dan mencari teman baru. Pengalaman komunikasi terbagi menjadi dua, yaitu komunikasi positif dan pengalaman komunikasi negatif. Pengalaman komunikasi positif menggambarkan jangkauan twitter lebih luas, media promosi dan informasi. Pengalaman komunikasi negatif banyaknya postingan, kebebasan konten lebih buruk, terjadi pembunuhan karakter serta etika berkomunikasi yang kurang baik. Interaksi sosial yang terjadi yaitu keefektifan pertukaran pesan, kesamaan ketertarikan, serta memberikan pemikiran baru.
\end{abstract}

Kata kunci: Model, Komunikasi Sosial, Media, Remaja, Twitter

\section{Pendahuluan}

Perkembangan teknologi memumudah aktivitas manusia dalam melakukan hubungan sosial untuk berinteraksi secara global dalam berbagai bidang.
Perkembangan ini memberikan ruang kebebasan bagi semua pengguna media yang dinilai sebagai bagian dari kehidupannya. Kehidupan modern saat ini sudah dilingkari oleh kehidupan beragam media yakni 
audio, visual, audio visual, serta digital. Perkembangan teknologi komunikasi dan komputer menyebabkan terjadinya perubahan budaya masyarakat seharihari, perkembangan ini tidak terlepas dari penggunaan media bagi kegiatan manusia dalam bidang ekonomi, sosial, politik maupun dalam upaya membangun opini dalam melestarikan adat dan kebudayaan. Media sosial merupakan saluran yang dapat digunakan dengan mudah untuk berpartisipasi, berbagi dan menciptakan isi meliputi blog, jejaring sosial, wiki, forum di dunia virtual. Media sosial sebagai "sebuah kelompok aplikasi berbasis internet yang membangun atas dasar ideologi dan teknologi web 2.0, dan yang memungkinkan penciptaan pertukaraan "user-generated content" (Kaplan \& Haenlin, 2010: 59).

Media sosial menjadi primadona baru dalam perkembangan media dunia, media sosial atau akrab disebut jejaring sosial ini juga menyita perhatian masyarakat Indonesia, pelajar SMA pada khususnya. Media sosial dinilai bisa menjadi wadah bagi karya, ide, tanggapan bahkan media untuk mengekspresikan keadaan yang terjadi. Hanya dengan membuat akun pribadi, para pengguna bisa mendapatkan kemudahan dalam menuliskan dan mempublikasikan karya maupun tanggapannya pada khalaya. Inilah yang menjadi daya tarik media sosial, ketika apa yang ditulis bisa dibaca, dipahami kemudian mendapatkan komentar dari orang lain. Beberapa jejaring sosial tersebut diantaranya Facebook, Twitter, Instagram, Path, Skype, YouTube.

Dari sekian banyak media sosial yang paling cepat pertumbuhannya adalah twitter, dengan cepat mengambil perhatian masyarakat Indonesia, remaja khususnya, kebanyakan isi dalam twitter adalah halhal pribadi dimana seorang berbagi cerita, opini, aktivitasnya, kepada orang-orang pilihan. Twitter hanya membuat ruang 140 karakter bagi penggunanya untuk mengirim pesan. Jumlah pesan yang pernah diposting oleh pengguna ditampilkan dalam halaman profil pengguna, sehingga siapapun yang melihat bisa mengetahui jumlah postingnya. Dilihat dari beberapa fitur, salah satu fitur yang sangat menarik dalam media sosial twitter yaitu fitur follower. Fitur ini bisa memberikan gambaran bagi pengguna bahwa bagi akun pengguna twitter yang mempunyai follower terbanyak menunjukkan akun tersebut dipersepsi mempunyai kredibilitas yang memengaruhi daya tarik tertentu.

Pengguna twitter sebagian besar adalah kalangan remaja termasuk para pelajar di lingkungan SMA Negeri di Kecamatan Ciamis. Motif penggunaan twitter ini merupakan wadah yang pantas untuk menyalurkan aspirasi, melihat karakter, motif perkembangan pergaulan, motif hiburan. Twitter tak terbatas ruang dan waktu, penyampaian dan penerimaan informasi yang cepat, eksistensi diri serta mencari relasi atau teman baru. Pengguna twitter juga menjadi saluran baru dalam komunikasi politik yang masif dipakai selama pilpres 2014. Karakternya yang interaktif, partisipatif dan terdesentralisasi menjadi latar belakang optimisme para ahli akan kemampuan media baru (Hasfi dkk, 2015: 270). 
Secara umum, motif adalah kebutuhan, keinginan dan dorongan. Motivasi seseorang juga tergantung kepada kekuatan motifnya. Motif dengan kekuatan yang cukup besarlah yang akan menentukan perilaku seseorang, dalam hal ini adalah para pelajar khususnya di SMA Negeri di Kecamatan Ciamis yang menjadi sasaran penelitian ini. Menurut Tria Yulius Sapitri dan Jurry Hatammimi (dalam Izzati, 2015: 374) bahwa kekuatan motif juga dapat berubah jika terpuaskannya kebutuhan dan jikalau kebutuhan sudah terpenuhi maka akan terjadi penurunan terhadap motif dan beralih kepada kebutuhan lain dan seterusnya, sedangkan motivasi adalah kemauan untuk berbuat sesuatu serta sebagai salah satu faktor penentu dalam pencapain tujuan. Motivasi berkaitan erat dengan dorongan atau kekuatan yang berada dalam diri manusia. Terlihat jelas, bahwa media sosial dewasa sekarang dijadikan agen kepentingan atau interest akan membuat seseorang selektif dalam menanggapi atau menghayati pesan. Orang hanya akan memperhatikan perangsang yang ada hubungannya dengan kepentingannya (Ardianto, 2007:84).

Kajian ini dapat dibedah melalui pemikiran Schutz dikenal dengan teori fenomenologis, yang merupakan kritikan schutz tentang pemikiran-pemikiran weber, selain Husserl tentang sosiologi (Schutz dalam Kuswarno 2009: 110). Fase diperlukan untuk menggambarkan keseluruhan tindakan seseorang. Dua fase yang diusulkan Schutz diberi nama tindakan in-orderto motive (Um-zu-Motiv), yang merujuk pada masa yang akan datang; dan tindakan because-motive (Weil-Motiv) yang merujuk pada masa lalu. Schutz mencontohkan, jika seseorang membuka payung ketika hujan turun, maka motif pertama ("Motif untuk") akan berupa pernyataan "menjaga baju tetap kering"; sedangkan motif kedua ("Motif sebab") dengan melihat pengalaman dan pengetahuan sebelumnya tentang bagaimana akibatnya pada baju jika hujan tanpa payung, misalnya digambarkan sebagai pernyataan "agar baju tidak basah" (Schutz dalam Kuswarno 2009: 110). Terkait dengan motif untuk (in-order-to motive)Schutz selanjutnya menjelaskan bahwa melihat ke depan pada masa yang akan datang (looking-foward into the future) merupakan hal yang esensial bagi konsep tindakan atau action (handeln). Tindakan adalah perilaku yang diarahkan untuk mewujudkan tujuan pada masa datang yang telah ditetapkan (determine). Kalimat tersebut sebenarnya mengandung makna juga bahwa seseorang memiliki masa lalu (pastness). Dengan demikian, tujuan tindakan memiliki elemen ke masa depan (futurity) dan elemen ke masa lalu (pastness). Untuk menggambarkan bahwa tujuan suatu tindakan sosial seseorang cukup kompleks, Schutz meminjam istilah tata bahasa, dengan menyebutin the future perfect tense (modo futuriexacti). Sementara itu, suatu tindakan dapat berupa "tindakan yang sedang berlangsung" (the action in progres), dan "tindakan yang telah lengkap" (the complected act). Dengan meminjam istilah dari Heidegger, Schutz menyebutkan bahwa "the completed act this pictured in the future perfect tense as the project (Entwurf) of the action". Apa yang disebut sebagai suatu "proyek", Schutz menjelaskan: "is the act which is the goal of the actions and which is brought into being 
by the action"(Schutz dalam Kuswarno 2009: 110-111).

Motif karena (because-motive), dalam konteks fenomenologis, pengguna twitter adalah aktor yang melakukan tindakan sosial bersama aktor lainnya sehingga memiliki kesamaan dan kebersamaan dalam ikatan makna intersubjektif. Para aktor tersebut juga memiliki historitas dan dapat dilihat dalam bentuk yang alami. Mengikuti pemikiran Schutz, pengguna twitter sebagai aktor mungkin memiliki salah satu dari dua motif, yaitu motif berorientasi ke masa lalu (because motives). Tentu saja motif tersebut akan menentukan penilaian terhadap dirinya sendiri dalam statusnya sebagai pengguna twitter. Menurut Scott dan Lyman, mungkin saja mereka tidak merasa sebagai pengguna twitter, dengan mengajukan pembelaan diri dengan mengemukakan alasan tertentu atau bahkan mungkin secara jujur dan penuh percaya diri menyatakan pembenaran (justification). Kondisi ini juga akan menentukan gambaran pengguna twitter menurut mereka sendiri terhadap alasan "masalaluyangmengakibatkan mereka menjadi pengguna twitter".

Penelitian ini juga tidak terlepas pada penelitian terdahulu. Ini dimaksudkan untuk memperkuat kajian penelitian yang ada. Penelitian terdahulu yang dijadikan referensi ini adalah Motif Penggunaan Media Sosial sebagai Sarana Promosi Bisnis Online di Kalangan Mahasiswa UIN Sunan Kalijaga. Penelitian ini bertujuan untuk mendeskripsikan motif penggunaan gadget sebagai sarana promosi bisnis online di kalangan mahasiswa UIN Sunan Kalijaga. Hasil penelitian ditemukan motif penggunaan media sosial sebagai sarana promosi bisnis online yaitu : Pertama, penggunaan media sosial dianggap lebih nyaman dan mudah dalam melakukan promosi, Kedua, Bisnis Online cocok dijalankan untuk usaha kecil dengan menjual beragam produk. Ketiga, Berbisnis secara langsung menggunakan media sosial merupakan inisiatif atau kesadaran diri dari informan dalam mencukupi sebagian kebutuhan serta melatih diri untuk menjadi sosok yang mandiri.

Berdasarkan hal tersebut, maka terkait dengan judul yang penulis lakukan tentang: Model Komunikasi Sosial Remaja Melalui Media Twitter, maka fokus kajiannya adalah : Bagaimana motif, pengalaman dan interaksi sosial dalam media sosial twitter dikalangan pelajar SMA Negeri di Kecamatan Ciamis? Penelitian ini bertujuan untuk menemukan dan menjelaskan motif, pengalaman dan interaksi sosial pengguna media twitter dikalangan pelajar SMA Negeri di Kecamatan Ciamis.

\section{Metode Penelitian}

Penelitian ini menggunakan pendekatan kualitatif.Pendekatanini,menitikberatkan pada observasi dan suasana ilmiah (natural setting). Peneliti terjun langsung kelapangan, bertindak sebagai pengamat untuk membuat kategori prilaku, mengamati gejala, dan mencatatnya dalam buku observasi. Terkait dengan judul model komunikasi sosial remaja melalui media twitter, peneliti dapat mempelajari bentukbentuk motif, pengalaman dan interaksi sosial dari para informan sebagai pengguna media sosial twitter dari sudut pandang orang yang mengalaminya langsung.

Pemilihan informan didasarkan kepada informan yang mampu menggambarkan kembali fenomenanya yang telah dialaminya terutama dalam sifat alamiah motif dan interaksinya, bersedia untuk terlibat dalam kegiatan penelitian, serta bersedia untuk 
diwawancara dan direkam aktivitasnya selama wawancara atau selamapenelitian berlangsung. Teknik pengumpulan data yang digunakan adalah wawancara mendalam, observasi partisipan dan studi pustaka. Mekanisme penentuan informan ini bagi menjadi 3 tahap diantaranya: (1) Mencari data jumlah pelajar dari setiap kelas. (2) Penyeleksian jumlah pelajar dengan menggunakan rasio perbandingan untuk menentukan berapa jumlah informan sebagai perwakilan. (3) Melakukan pemilihan informan dari daftar teman follower atau yang mempunyai akun twitter yang aktif di daftar follower.

Jumlah informan utama yang digunakan adalah 17 orang dari tiga SMA Negeri yang ada di Kecamatan Ciamis, yaitu SMA Negeri 1 Ciamis, SMA Negeri 2 Ciamis, SMA Negeri 3 Ciamis. Sedangkan narasumber ada 1 orang yaitu Bapak Agung Syaputra. Teknik pemilihan informan ini menggunakan teknik purposif (Nurhadi, 2012:). Teknik ini dilakukan dengan cara peneliti sudah menentukan sejumlah informan secara purposif, sesuai dengan tujuan yang ingin diperoleh.

\section{Hasil Penelitian dan Pembahasan}

Hasil penelitian ini, menguraikan tentang aspek-aspek yang terkait dengan motif, pengalaman dan interaksi sosial penggunaan media sosial twitter dikalangan pelajar SMA Negeri di Kecamatan Ciamis, yaitu:

\section{Motif Pelajar SMA Negeri Menggunakan Media Sosial Twitter}

Perilaku mahasiswa pengguna media sosial twitter didasari oleh adanya kekuatan yang mendorongnya baik dari dalam diri mahasiswa maupun dari luar. Kekuatan dari dalam yang mendorong mahasiswa untuk berperilaku disebut motif. Berdasarkan hasil yang dilakukan, peneliti mendapatkan hasil yang beragam mengenai motif, pengalaman dan interaksi sosial mahasiswa dalam menggunakan media social twitter. Motif yang dihasilkan terbagi dalam dua kategori jenis motif yaitu motif "in order to", artinya bahwa sesuatu merupakan tujuan yang digambarkan sebagai maksud, rencana, harapan, minat, dan sebagainya yang berorientasi pada masa depan. Jenis motif ini lebih kepada alasan seseorang melakukan tindakan sebagai usahanya menciptakan situasi dan kondisi yang diharapkan dimasa yang akan datang atau harapan dimasa yang akan datang. Motif 'karena' (because motives), artinya sesuatu merujuk pada pengalaman masa lalu individu, karena itu berorientasi pada masa lalu, yaitu dimana aktor atau seseorang merujuk pada beberapa faktor yang berkaitan dengan pengalaman masa lalu yang dilakukan oleh informan.

Motif yang mendasari pelajar SMA Negeri di Kecamatan Ciamis menggunakan twitter dalam aktivitasnya bermacammacam bisa dilihat seperti dalam tabel 1 .

\section{Pengalaman Pelajar SMA Negeri Menggunak- an Media Sosial Twitter}

Pengalaman komunikasi yang dianalisis adalah pengalaman pelajar SMA yang memilih media social twitter sebagai media yang mereka pakai untuk aktivitas keseharianya, juga bagaimana pelajar tersebut menggunakan media social twitter dalam berinteraksi dengan pengguna lain.

Setiap pelajar tentu memiliki berbagai pengalaman komunikasi saat mereka baru saja menggunakan media sosial twitter. Berikut beberapa penuturan terkait dengan 
Tabel 1 Model Motif Pengguna Media Sosial Twitter

\begin{tabular}{l} 
Penjelasan Motif \\
\hline Motif Perkembangan lingkungan pergaulan dan teknologi. Jenis motif ini adanya dorongan \\
dari lingkungan pergaulannya yang banyak menggunakan mediasosial twitter dan perubahan \\
teknologi yang begitu cepat.
\end{tabular}

Motif Banyak yang menarik. Jenis motif ini bahwa dorongan yang muncul menggunakan media sosial twitter dari dirinya sendiri, tidak ada persuasive dari orang lain. Hal ini, dengan menggunakan media sosial twitter dapat memenuhi kebutuhan informasi dan hiburan yang menarik.

Motif Hiburan. Jenis motif ini menggambarkan bahwa media sosial twitter dapat memberikan informasi hiburan yang memberikan kepuasan bagi pengguna atas ketertarikannya pada isi konten dalam memenuhi kebutuhannya.

Motif Tak terbatas ruang dan waktu. Jenis motif ini memberikan kebebasan kepada pengguna media sosial twitter dalam penggunaannya sehingga media sosial ini tidak hanya digunakan untuk mencari informasi yang dibatasi waktu, akan tetapi dijadikan sebagai agen bisnis dalam setiap saat.

Motif Penyampaian dan penerimaan pesan cepat. Jenis motif ini menggambarkan bahwa media sosial twitter berdasarkan penuturan dari informan, dalam proses penyampaian dan penerimaan pesan lebih cepat dibandingkan dengan yang lainnya.

Motif Eksistensi Diri. Jenis motif ini menggambarkan bahwa pengguna media social twitter ketertarikannya lebih kepada menunjukkan eksistensi diri di dunia maya (narsis) dengan tujuan untuk dikenal oleh banyak pengguna twitter lainnya.

Motif Bisnis. Jenis motif ini menggambarkan bahwa pengguna mediasosial twitter menjadikan sebagai media promosi bisnis, dikarenakan informan memiliki keahlian, sehingga memanfaatkan media social sebagai kreativitas.

Kategori

Because

Because

Because

Because

Motif Mencari Relasi/teman baru. Jenis motif ini menggambarkan bahwa dari sekian motif yang ada, bahwa pengguna media sosial twitter juga bertujuan untuk mencari relasi atau teman baru sebagai sarana untuk menambah jumlah follower.

Sumber: Hasil penelitian berdasarkan data Informan, 2016

pengalaman komunikasi dari setiap informan yang terlihat pada tabel 2 .

Interaksi Sosial Yang Terjadi Pada Pelajar SMA Negeri Dalam Menggunakan Media

\section{Sosial Twitter}

Interaksi sosial merupakan suatu hubungan di mana terjadi proses saling pengaruh memengaruhi antara para individu, antara individu dengan kelompok, maupun antara kelompok.ProsesKomunikasipadahakikatnya adalah proses penyampaian pemikiran, atau perasaan oleh seseorang (komunikator) kepada orang lain (komunikan). Pikiran bisa merupakan gagasan, informasi, opini, dan lainlain yang muncul dari benaknya. Perasaan bisa berupa keyakinan, kepastian, keraguan, kekhawatiran, kemarahan, keberanian, kegairahan, dan sebagainya yang timbul dari lubuk hati (Bungin, 2008:17).

Interaksi sosial merupakan hubungan sosial yang dinamis menyangkut hubungan antara orang perorangan, antara kelompokkelompok manusia, maupun antara orang perorangan dengan kelompok manusia (Soekanto, 2002: 62). Syarat terjadinya interaksi sosial adalah adanya kontak sosial (sosial contact) dan adanya komunikasi (communication). Perspektif interaksi simbolik mengandung dasar pemikiran yang sama dengan teori tindakan sosial tentang 'makna subjektif' (subjective meaning) dari perilaku manusia, proses sosial dan pragmatisnya. Terdapat beberapa versi interaksionisme simbolik, dalam 
Tabel 2. Model Pengalaman Komunikasi Media Sosial Twitter

\section{Penjelasan Tentang Pengalaman}

Kategori

Pengalaman

Media sosial twitter dipilih lebih tepat. Bahwa mediasosial dipilih berdasarkan pengalaman informan merasakan bahwa selama menggunakannya banyak memberikan kemudahan, kenyamanan, serta aspek penyebaran pesan maupun pencarian tentang informasi dan pemanfaatan digunakan sesuai dan tepat berdasarkan fungsinya.

Penggunaan mediasosial twitter lebih leluasa. Pengalaman informan menuturkan bahwa pengguna mediasosial twitter berkenaan tentang fitur yang ada dalam media sosial memiliki kesederhanaan dan kegunaan sehingga lebih leluasa dalam menggunakannya (mudah dipahami).

Pengguna dan jangkauan media sosial twitter memiliki jumlah/follower yang banyak. Jangkauan media sosial twitter memiliki keleluasaan dalam hal mengirim/menerima, sehingga aspek ruang dan waktu bukan menjadi penghambat yang bisa mengganggu aktivitasnya.

Kemudahan dalam mengakses twitter. Bahwa kemudahan dapat menunjang akan kebutuhan informasi yang ingin didapatkan sehingga dapat terpenuhi dengan baik.

Publikasi melalui media sosial twitter lebih efektif. Publikasi berupa pesan terbilang sudah efektif berdasarkan pengalamannya. Bahwa pesan yang diposting pengguna dapat diakses dengan cepat dan mudah oleh pengguna lain sehingga apa yang diinginkan para pengguna mudah untuk didapatkan.

Dalam mengakses tidak mengenal batasan ruang dan waktu. Penggunaan media social twitter dirasakan tidak dibatasi ruang dan waktu artinya dapat diakses kapanpun dan di manapun.

Tumbuhnya perasaan senang saat pengguna lain memberikan respon. Dalam hal ini, adanya kecenderungan ingin mendapatkan perhatian lebih dengan aktivitas di media social twitter, ketika informan pengguna twitter melakukan aktivitasnya dan mendapat respon, hal tersebut menimbulkan adanya rasa senang dan diakui oleh pengguna lain.

Pengalaman

Komunikasi Positif Media sosial twitter sebagai media promosi dan informasi. Hal ini menunjukkan adanya pemanfaatan media sosial twitter sebagai salah satu media promosi dalam kegiatan/ aktivitasnya.

Banyak yang memposting yang tak seharusnya di posting. Pengalaman ini merupakan salah satu yang dialami oleh informan selama menggunakan media sosial twitter terkadang dalam mempublikasikan banyak hal berkenaan dengan menyinggung perasaan pengguna lain.

Kebebasan konten memiliki efek yang buruk. Pengalaman ini dirasakan informan berkenaan dengan isi konten yang seharusnya tidak dipublikasikan, dengan kebebasan tersebut dapat memberikan dampak yang banyak merugikan orang lain.

Terjadi kasus bullying verbal dan non verbal. Pengalaman yang buruk terjadi akibat dari rutinitas yang buruk serta kebiasaan yang seharusnya tidak ditunjukkan di mediasosial twitter seperti pertengkaran maupun konflik bisa mengakibatkan keadaan yang tidak baik

Terjadi pembunuhan karakter. Tidak adanya saling menghargai, saling menjatuhkan akan berdampak pada berkurangnya rasa hormat dalam diri seseorang.

Etika yang kurang baik ketika berkomunikasi. Pengalaman komunikasi ini menjelaskan dalam media social twitter semua pengguna kadang dianggap sama rata meskipun adanya perbedaan usia atau jenis kelamin/gender, sehingga ketika komunikasi berjalan yang dilakukannya itu dapat menyalahi etika / batas kewajaran.

Sumber: Hasil penelitian berdasarkan data Informan, 2016

pemaparan kualitatif yang bersumber dari pemikiran fenomenologis, mengukuhkan teori interaksi simbolik sebagai suatu kajian ilmiah tentang berbagai aspek subjektif manusia dalam kehidupan sosial. Terdapat esensi bahwa komunikasi atau pertukaran
Pengalaman

Komunikasi

Negatif 
simbol yang diberi makna merupakan suatu aktivitas yang khas di antara manusia (Cangara, 2008: 16). Selain itu, seseorang akan menjadi manusiawi hanya melalui interaksi dengan sesamanya. Interaksi yang terjadi antar manusia akan membentuk masyarakat. Manusia secara aktif membentuk perilakunya sendiri (Kuswarno, 2009: 113-114).

Pemikiran interaksi sosial ini menjadi dasar untuk menjelaskan bagaimana interaksi sosial yang terjadi di dalam media sosial twitter kalangan pelajar SMA Negeri di Kecamatan Ciamis tersebut. Berdasarkan hasil wawancara yang dilakukan, penulis mendapatkan hasil yang beragam mengenai interaksi social dikalangan pelajar SMA Negeri di Kecamatan Ciamis berkenaan penggunaan media sosial twitter. Hal ini dapat dilihat di tabel 3.

Salah satu yang menjadi kegiatan manusia dalam penelitian ini adalah menggunakan media sosial twitter.

Tabel 3. Model Interaksi Sosial Pengguna Media Sosial Twitter

\begin{tabular}{l}
\hline Penjelasan Interaksi Sosial Pengguna Media Twitter \\
\hline Twitter mudah di gunakan dalam berinteraksi sosial. Interaksi yang terjadi di media sosial twitter bagi informan \\
pelajar SMA memudahkan mereka untuk melakukan kegiatan interaksi sosial, karena di media sosial twitter \\
interaksi sosial terjadi secara alami, sadar maupun tidak sadar sesama pengguna saling merespon dari setiap \\
aktivitas mereka di twitter karena adanya proses komunikasi penyampaian dan penerimaan informasi ataupun \\
pesan sesuai maksud dan tujuan masing-masing.
\end{tabular}

Keefektifan pertukaran pesan tergantung akan beberapa diantaranya fasilitas yang menunjang dalam menggunakan twitter. Dalam suatu peristiwa interaksi sosial bagi informan pelajar SMA menggunakan twitter menjadi salah satu media yang memberikan cara baru dalam pertukaran pesan yang cukup efektif, keefektifan media sosial twitter tergantung dari aspek pendukung yang dapat membantu proses pertukaran pesan berjalan efektif dengan adanya jaringan internet yang yang selalu tersedia dan aspek peralatan yang menunjang untuk lebih memudahkan dalam proses interaksi sosial.

Kesamaan ketertarikan dapat terjadinya timbal balik yang positif. Daya tarik dari pemicu terjadinya interaksi sosial dalam media sosial twitter ini bagi pelajar SMA yaitu adanya tujuan yang sama dari para pengguna media sosial twitter ini seperti adanya suatu kesamaan ketertarikan dalam segi topik tertentu yang ada di twitter sehingga menimbulkan timbal balik yang positif satu sama lain sesama pengguna media sosial twitter.

Topik yang diperbincangkan dengan pengguna lain dapat memberikan pemikiran baru. Isi konten dalam media sosial twitter adalah salah satu hasil dari peristiwa interaksi sosial yang terjadi dalam media sosial twitter salah satunya topik yang di perbincangan oleh para pengguna media sosial twitter dengan adanya topik yang di perbincangkan memberikan berbagai pemikiran yang baru sehingga bisa mengembangkan topik tersebut menjadi suatu yang bernilai bagi para pengguna media sosial twitter yang lain.

Kebebasan akan menyampaikan pesan serta mendapatkan pesan bisa menghasilkan ide kreatif dan inovatif dalam media sosial twitter kebebasan dalam berinteraksi sosial dalam menyampaikan pesan maupun mendapatkan pesan memberikan kemudahan dalam menghasilkan ide kreatif dan inovatif dari proses interaksi sosialini bisa menginsiprasi pengguna lain dalam menyerap hasil dari interaksi yang terjadi di media sosial twitter.

Isi konten dalam twitter merupakan pemicu terjadinya interaksi sosial bagi para pengguna media sosial ini, dengan berbagai konten yang ada berdasarkan ketertarikan para pengguna media sosial twitter bisa memberikan rangsangan bagi para pengguna untuk saling berinteraksi, berdasarkan adanya isi konten yang menarik bagi para penggunanya menciptakan saling ketertarikan satu sama lain dalam pertukaran informasi ataupun yang lainya.

Peran sosial menunjang sebuah interaksi sosial dalam berkomunikasi di media sosial twitter. Peran sosial yang ada di dalam media sosial twitter ini menunjang akan terjadinya proses komunikasi yang memicu sebuah interaksi sosial di media sosial twitter dengan peran sosial yang ada pada diri pengguna twitter, menjadikan kendali bagi mereka untuk melakukan interaksi dengan pengguna lain sama halnya dengan ruang lingkup dalam lingkungan pergaulan di dalam masyarakat. 
Penggunaan media sosial twitter telah menjadi fenomena yang cukup menarik untuk diperbincangkan. Pada kenyataannya memang banyak masyarakat di Indonesia yang menggunakan media sosial twitter sebagai media baru dalam kehidupan sosialnya khususnya dikalangan pelajar SMA Negeri Kecamatan Ciamis. Dalam penggunaan media sosial twitter ini, setiap orang yang menggunakannya pasti memiliki motif tersendiri ketika memutuskan untuk menggunakan media sosial twitter.

Media sosial khususnya twitter memberikan kesempatan untuk berinteraksi lebih dekat dengan pengguna, dapat menjadi media untuk membentuk jaringan komunitas. Media sosial dapat menjadi bagian dari keseluruhan marketing strategy yang digabungkan melalui media sosial lainnya, serta sebagai jalan menemukan atau menciptakan para brand evangelist. Media sosial memberikan peluang masuk komunitas yang telah ada sebelumnya dan memberikan kesempatan mendapatkan feedback secara langsung (Elcom, 2009: 21).

Pengalaman komunikasi positif berarti mengandung pesan serta efek yang positif. Pesan tersebut dapat berupa pesan verbal maupun non verbal. Pengalaman komunikasi jenis ini menjadi sangat berarti bagi pelajar SMA pengguna media social twitter dalam menjalankan aktivitasnya. Hal terebut dapat menjadi dorongan positif bagi mereka. Pengalaman ini terbentuk dari proses komunikasi yang terjadi, terutama komunikasi new media, karena pada penelitian ini objek penelitiannya terhubung dengan kegiatan pelajar SMA Negeri di Kecamatan Ciamis penggunaan media sosial twitter, baik persepsi, pengalaman, maupun pengetahuan akan terbentuk akibat dari proses komunikasi yang terjadi antara pengguna twitter.

Pengguna memakai twitter dalam memulai rutinitasnya, pengguna tersebut memiliki tujuan memilih media sosial twitter. Pengguna media sosial menggunakan media sosial twitter untuk mendapatkan keuntungan melalui jaringan internet. Pengguna twitter memilih media sosial twitter sebagai wadah atau tempat melakukan pertukaran informasi atau penyebaran informasi sehingga informasi tersebut dapat sampai ke pengguna lain dan akhirnya terjadi sebuah interaksi sosial.

Pengalaman komunikasi negatif berasal daripesan danfeedbackyang negatif.Adanya kesalahan dalam proses komunikasi yang terjadi sehingga menimbulkan efek negatif. Efek itu bisa berupa tindakan, perilaku maupun pengalaman pribadi seseorang. Hal ini bukan menjadi penghalang karena pengguna dapat menelaah kembali dan mencari jalan keluarnya sehingga tidak terjadi pengalaman seperti itu lagi, atau memperkecil kemungkinan terjadinya hal tersebut kembali.

Interaksionisme simbolik mempelajari sifat interaksi yang merupakan kegiatan sosial dinamis manusia. Bagi perspektif ini, individu bersifat aktif, reflektif, dan kreatif, menafsirkan, menampilkan perilaku yang rumit dan sulit diramalkan (Gerungan, 2010:34). Paham ini menolak gagasan bahwa individu adalah organisme yang pasif yang perilakunya ditentukan oleh kekuatankekuatan atau struktur yangada diluar dirinya. Oleh karena individu terus berubah maka masyarakat pun berubah melalui 
interaksi. Jadi interaksilah yang dianggap sebagai variabel penting yang menentukan perilaku manusia bukan struktur masyarakat (Mulyana, 2005: 29).

Selain dari hasil wawancara dengan informan, peneliti juga melakukan proses triangulasi dengan melakukan wawancara pada Agung Syaputra sebagai narasumber. Agung Syaputra ini adalah salah satu staff kepala editor bidang periklanan sekaligus salah satu pendiri di perusahaan penerbitan tabloid dan media online InfoMedia Group. Ia mempunyai akun media sosial twitter, dan sudah menggunakan media sosial twitter selama kurang lebih 7 tahun sejak 2009 sampai 2017. Akun twitternya mempunyai 8,621 tweet atau postingan, 968 follower serta 692 following. Dia menjelaskan adanya media sosial twitter memberikan peluang baginya untuk memanfaatkanya sebagai suatu bidang bisnis di kemudian hari.

Berkaitan dengan media sosial twitter menurut Agung Syaputra banyak hal yang bisa dimanfaatkan dengan media sosial ini tetapi terkadang tidak banyak orang memanfaatkan media sosial ini lebih jauh, tidak lebih dari sekedar media yang memfasilitasi untuk mengisi waktu luang para pengguna twitter, dalam kajian penelitian ini Agung memaparkan beberapa pernyataan tentang motif, pengalaman, dan interaksi sosial, baginya media sosial twitter berkaitan dengan tiga kajian ini merupakan satu kesatuan yang saling mendukung dalam proses komunikasi, hal ini sesuai secara psikologi, ketika individu melakukan komunikasi dengan orang lain atau melalui perantara (medium), akan terbangun proses komunikasi secara mental yang mendorong untuk melakukan tindakan komunikasi sehingga hal tersebut menjadikan kesatuan utuh dalam aktivitas kehidupannya (Sobur, 2003: 54).

\section{Simpulan}

Motif yang mendorong penggunaan media sosial twitter dikalangan pelajar SMA Negeri Kecamatan Ciamis yaitu untuk mencari dan menggali informasi terkait bidang yang mereka suka. Bidangbidang tersebut ada yang berkaitan dengan komunikasi bahkan tidak. Bidang tersebut mulai dari olahraga, fotografi, sastra, seni dan aksesorisnya. Hal ini, dikarenakan fitur twitter yang simpel dan singkat dibanding media sosial lain. Melalui twitter pengguna banyak menemukan informasi baru yang kemudian jadi bahan perbincangan di dunia nyata.

Pegalaman penggunaan media sosial twitter dikalangan pelajar SMA Negeri Kecamatan Ciamis berkaitan pesan-pesan yang diposting oleh informan beragam, mulai dari curahan hati, informasi pelajaran, rayuan-rayuan, guyonan ringan, hingga kalimat-kalimat bernada motivasi. Sebagian informan mengaku hal tersebut dilakukan untuk pencitraan positif dari pembaca. Kategori pesan yang rata-rata tidak disukai oleh informan adalah pesan bernada galau, mengeluh dan pesan kasar bernada marahmarah. Semua informan merasa percaya diri ketika mereka memiliki akun twitter dan aktif dalam penggunaannya. Hal ini, terlihat pada frekuensi posting yang mereka lakukan.

Interaksi sosial dapat dijalankan lewat twitter, mengingat banyak teman dari yang 
mereka tinggal berjauhan, dan twitter sebagai sarana untuk menuliskan pesan yang ringan bagi mereka, hal Ini terlihat dari beberapa percakapan yang dilakukan informan kepada teman yang tinggal berjauhan. Keefektivitasan twitter sebagai sarana komunikasi tergantung pada alat komunikasi yang digunakan. Alat komunikasi berupa smartphone dianggap yang paling efektif untuk menggunakan twitter. Ini terlihat pada frekuensi pesan yang lebih sering daripada pengguna aplikasi komputer lain. Twitter sebagai media hiburan yang positif dan informatif dibandingkan televisi.

Berikut beberapa saran untuk penggunaan lebih efektif :

Penggunaan media sosial twitter, alangkah lebih baiknya jika setiap pelajar di SMA Negeri Kecamatan Ciamis mempunyai akun twitter. Akun ini dapat di manfaatkan untuk menginformasikan pengumuman penting bagi para pelajar mengenai perkembangan media sosial ataupun dalam proses kegiatan belajar mengajar. Penggunaan twitter bisa lebih efektif dan efisien bagi para pelajar yang menggunakannya, sehingga tidak mengganggu waktu belajar.

\section{Daftar Pustaka}

Ardianto, Elvinaro. (2007). Komunikasi Massa: Suatu Pengantar. Bandung: Simbiosa Rekatama Media.

Bungin, Burhan. (2008). Sosiologi Komunikasi (Teori, paradigma, dan Discourse Teknologi Komunikasi di Masyarakat). Jakarta: Kencana Prenada Media Group.
Cangara, Hafied. (2008). Pengantar Ilmu Komunikasi. Jakarta: PT.Raja Garfindo Persada.

Gerungan, W.A. (2010). Psikologi Sosial. Bandung: PT. Refika aditama.

Kaplan, Andreas M \& Michael Haenlein. (2010). Users of the Word, Unite! The Challenges and Opportunities of Social Media. Business Horizons.

Kuswarno, Engkus. (2009). Metodologi Penelitian Komunikasi: Fenomenologi, Konsepsi, Pedoman dan Contoh Penelitiannya. Bandung: Widya Pajajaran.

Mulyana, Deddy. (2005). Ilmu Komunikasi: Suatu Pengantar. Bandung: Remaja Rosdakarya.

Nurhadi, Zikri Fachrul. (2012). Metodologi Penelitian Kualitatif (Teori dan Paradigma). Bandung: CV Alfabeta.

Izzati, Nurul. (2015). Motif Penggunaan Gadget Sebagai Sarana Promosi Bisnis Online di Kalangan Mahasiswa UIN Sunan Kalijaga. Jurnal Komunikasi ASPIKOM,Volume 2 Nomor 5, Juli, Hal 374-380.

Hasfi, Nurul, dkk. (2017). Refresentasi Kepemimpinan Calon Presiden di Twitter, Jurnal Komunikasi ASPIKOM, Volume 3 Nomor 2, Januari, Hal 270-284.

Elcom. (2009). Twitter:Best Sosial Networking. Jakarta: Penerbit Andi Jogjakarta

Sobur, Alex. (2003). Psikologi Umum. Bandung: Pustaka Setia.

Soekanto.(2002). Interaksi Sosial. Yogyakarta: Kencana Setia. 